\title{
Crumbling, creeping or enduring - the foundations of legal knowledge at a time of training reform (Amicus Curiae 104)
}

Article $\cdot$ December 2016

CITATION

1

2 authors, including:

James Hand

University of Portsmouth

20 PUBLICATIONS 25 CITATIONS

SEE PROFILE
READS

6 
This is a pre-print of an article that has been accepted for publication in Amicus Curiae (the official journal of the Society for Advanced Legal Studies and the Institute of Advanced Legal Studies (a member institute of the School of Advanced Study, University of London). The definitive version appears in issue 104 and will in time appear at http://ials.sas.ac.uk/digital/sas-open-journals/amicus-curiae/amicus-curiae-2015 and/or http://journals.sas.ac.uk/amicus/issue/archive. This version (C) the authors.

Crumbling, creeping or enduring - the foundations of legal knowledge at a time of training reform
James Hand
$\&$
Claire Sparrow

Associate Senior Lecturer

Principal Lecturer

\author{
School of Law, \\ Portsmouth Business School, \\ University of Portsmouth, \\ Richmond Building, \\ Portland Street, \\ Portsmouth
}

PO1 3DE

email: James.Hand@port.ac.uk, Claire.Sparrow@port.ac.uk 
This is a pre-print of an article that has been accepted for publication in Amicus Curiae (the official journal of the Society for Advanced Legal Studies and the Institute of Advanced Legal Studies (a member institute of the School of Advanced Study, University of London). The definitive version appears in issue 104 and will in time appear at http://ials.sas.ac.uk/digital/sas-open-journals/amicus-curiae/amicus-curiae-2015 and/or

http://journals.sas.ac.uk/amicus/issue/archive. This version (c) the authors.

\section{Crumbling, creeping or enduring - the foundations of legal knowledge at a time of training reform}

Legal Education periodically goes through periods of potential flux. There have been at least five major reviews within the last 50 years comprising two Command Papers - Cmnd 4595 ('the Ormrod Report' of 1971) and Cmnd 7648 ('the Benson Report' of 1979)) and three reports by the profession (including one by the short lived Advisory Committee on Legal Education and Conduct (ACLEC)). We are currently in the midst of the individual regulatory bodies' responses to the latest of those reviews - the Legal Education and Training Review 2013. While a range of issues are up for consideration including the work-based element of training and the general requirement of having a degree, the likelihood is that foundation subjects will remain, to the dissatisfaction of some.

\section{The seven foundations of legal knowledge}

In 1971 the Ormrod Report, having surveyed the content of law degrees, identified five 'core' subjects: constitutional, criminal, land, contract and tort (as well as the English Legal system). Equity and Trusts was subsequently added. While the continued existence of core subjects was challenged in a 1994 consultation paper by ACLEC, before they reported the profession announced, in 1995 and with ACLEC's acceptance, the replacement of the six core subjects with the seven foundations of legal knowledge which saw both European Community Law join the others and some additions to the content of the original six. The stated rationale for the foundation subjects was that they:

'arise from the fact that all prospective solicitors and barristers need a common grounding in these seven law foundations and because the vocational courses build on the students' knowledge of these foundations and must therefore be able to presuppose certain levels of familiarity, knowledge, awareness and appreciation. The foundations ... also provide the basis for continuing legal education and professional development by providing solicitors and barristers with the necessary knowledge to enable them to break into new areas of law.' (ACLEC, 1996, 117 (Annex D))

The expansion in 1995, which fettered the anticipated possible abolition following the ACLEC report, was roundly condemned by Peter Birks who opined, among other trenchant criticism, that 'The greatest absurdity which will now be continued for the best part of a decade is the combination of a list of compulsory subjects and the impossibility of substitution' (Birks, 1995). William Twining referred to this in his 2015 keynote at the Association of Law Teacher's conference as the 'creeping core' which could go on to see the inclusion of 'company law, ethics and values (which might lead to Jurisprudence being compulsory) or pet specialisms of successful individuals' and Richard Moorhead has written of 'chopping a few - quite a few fingers' off the dead hand on the curriculum rather than seeing its grip tighten (e.g. at https://lawyerwatch.wordpress.com/2015/12/10/sqeal-some-initial-thoughts-on-training-for- 
This is a pre-print of an article that has been accepted for publication in Amicus Curiae (the official journal of the Society for Advanced Legal Studies and the Institute of Advanced Legal Studies (a member institute of the School of Advanced Study, University of London). The definitive version appears in issue 104 and will in time appear at http://ials.sas.ac.uk/digital/sas-open-journals/amicus-curiae/amicus-curiae-2015 and/or

http://journals.sas.ac.uk/amicus/issue/archive. This version (c) the authors.

tomorrow/). The 2013 Legal Education Training Review, a joint project of the solicitors', barristers' and chartered legal executives' regulatory bodies, was hoped by some to be an opportunity to abandon the prescription of subjects but the report concluded that 'the range of evidence points to the existing Foundation subjects as a reasonable proxy for what is required' (LETR, 2013, para 7.93). The individual regulators' responses to the report suggest a list of foundations - but possibly not a qualifying law degree - will remain.

\section{The SRA's Competence Statement (and Statement of Legal Knowledge) and the BSB's Professional Statement}

The SRA and BSB have consulted separately on how to realise the issues raised in the LETR about access to the professions and how to assure the standards of those recognised as qualified solicitors and barristers. The SRA process, 'Training for Tomorrow' is slightly ahead of the BSB's 'Future Bar Training' consultation but both have published statements setting out the competences expected of solicitors and barristers at the point of qualification.

Turning first to the SRA, it published its 'Statement of Solicitor Competence' (Solicitors' Regulation Authority 2015a) on 1st April 2015. The competence statement requires solicitors to be able to spot issues that 'are outside their expertise and [take] appropriate action, using both an awareness of a broad base of legal knowledge (insofar as relevant to their practice area) and detailed knowledge of their practice area' (2015a, para. A.4c). That 'broad base' is defined in detail as:

'Legal System of England and Wales, constitutional law and EU law (including human rights), contract law, torts, ethics, professional conduct and regulation, including money laundering and solicitors accounts, criminal law and evidence, criminal litigation, civil litigation, property law, wills and administration of estates, trusts and equitable wrongs, law of and taxation, and other areas relevant to the solicitor's particular field of practice.' (Solicitors' Regulation Authority 2015a, n. 1)

The legal knowledge therefore expected of a qualifying solicitor seems to include all of the present foundation subjects set out in the existing Joint Statement (Law Society and General Council of the Bar 1999) as well as a substantial range of other subjects which might currently be expected to be covered on a Legal Practice Course (LPC). A detailed breakdown of each area is provided in the 'Statement of Legal Knowledge' (Solicitors' Regulation Authority 2015b) and shows no reduction in the breadth of knowledge that a solicitor is expected to demonstrate or in the degree of coverage of the foundation subjects. Indeed, part 11 of the Statement (covering Constitutional law and EU law (including Human Rights)), to take one example, identifies nine elements and replicates not just the content but much of the wording used in a comparable provision in the Joint Academic Stage Board Handbook 2010 (Appendix $M, 2$.ii.b, regarding partial exemption from the conversion course). While there are some differences in the other foundations, they are generally the explicit inclusion of topics 
This is a pre-print of an article that has been accepted for publication in Amicus Curiae (the official journal of the Society for Advanced Legal Studies and the Institute of Advanced Legal Studies (a member institute of the School of Advanced Study, University of London). The definitive version appears in issue 104 and will in time appear at http://ials.sas.ac.uk/digital/sas-open-journals/amicus-curiae/amicus-curiae-2015 and/or

http://journals.sas.ac.uk/amicus/issue/archive. This version (c) the authors.

generally taught (such as trespass to the person in part 6 Tort and sexual offences in part 7 Criminal) or matters typically covered in the LPC (such as stamp duty in Part 5 Property).

The BSB published its own 'Professional Statement for Barristers' in October 2015 which set out the 'day one' competences for a barrister in terms of knowledge, skills and attributes. In relation to knowledge, the Professional Statement sets out that a qualifying barrister will 'have a knowledge and understanding of the key concepts and principles of public and private law'. This will comprise '... the general principles of law underpinning the legal system of England and Wales, including the implications of EU law....' (Bar Standards Board 2015b, para. 1.2). There is no more concrete information as yet on what the BSB's approach will be to the Foundation subjects. Previously, there was an indication (in February 2015) that a less prescriptive approach might be taken where the BSB considered its approach to review of the academic stage: 'We will continue to require candidates for the Bar to have knowledge of law - but we expect to place more emphasis on principles, concepts, the ability to think and research independently, and on the other skills of a lawyer' (2015a,11). However, in 'Future Bar Training Consultation on the Future of Training for the Bar: Academic, Vocational and Professional Stages of Training Summary of responses' (January 2016), the BSB noted that 'many respondents supported the continuation of the specification of core subjects' (2016a, para 1.3) with 'a large number' holding that the 'current academic curriculum did not require significant change' (2016a, para 15.1). In their most recent consultation (on the threshold standard and competences) the BSB explains that it has 'worked with the Solicitors Regulation Authority to ensure consistency of requirements between the two professions where our training intersects, and particularly in relation to the academic stage, where divergent competences could make a coordinated approach unworkable' (Bar Standards Board 2016b, para. 6). Nonetheless, a particular divergence is under contemplation.

\section{The SRA's 'SQE' consultation}

Following on from their competence statement, the SRA reviewed how to assess intending solicitors against it and in December 2015 it proposed a two-stage 'Solicitors Qualifying Examination' in which the first part would assess knowledge with the subsequent part assessing skills (Solicitors' Regulation Authority, 2015c). While stage one would be modularised to allow the component assessments to be taken over time (para 43), no exemptions were planned for those who studied a qualifying law degree (para 45). Far from heralding the end of the foundations of legal knowledge subjects the SRA added ethics and professional conduct, wills and probate, taxation, business law and practice and litigation within stage one which raised the prospect of further restricting the undergraduate curriculum if law schools were to frame their law degrees as full preparation for stage one. The proposals were roundly criticised: of 250 responses, 200 were described as raising minor or serious concern with the remaining 50 being 'mixed' (see e.g. Smith, 2016) and the SRA decided to pause for thought and re-consult later in the year. 
This is a pre-print of an article that has been accepted for publication in Amicus Curiae (the official journal of the Society for Advanced Legal Studies and the Institute of Advanced Legal Studies (a member institute of the School of Advanced Study, University of London). The definitive version appears in issue 104 and will in time appear at http://ials.sas.ac.uk/digital/sas-open-journals/amicus-curiae/amicus-curiae-2015 and/or

http://journals.sas.ac.uk/amicus/issue/archive. This version (c) the authors.

The Bar Council, in their response to the consultation, considered that 'regardless of any changes that the SRA may consider in relation to solicitors' training, the Bar should remain a graduate-only profession' (General Council of the Bar, 2016) and were concerned about requiring students to decide too early on which path to follow (para 7). Similarly the Law Society $(2016$, p.5) warned:

The insistence from the SRA that there will be no qualifying element to a law degree essentially forces students to choose which profession they wish to enter at a much earlier date. Indeed, if the SRA are correct in their assumption that some universities will alter their courses to meet the requirements of the SQE, then students may be forced to decide when they apply for university which profession to aim for.

Separating the true, common foundations from the additional day one requirements of a solicitor would allow such decisions to be made at a more appropriate time. Allowing exemptions would also provide flexibility to students and allow the academy to serve wider interests. It would, furthermore, help remove the paradox of purportedly reduced regulation having a more constrictive effect.

\section{Foundations and the future}

The concept of foundation subjects has widespread acceptance in practice (as well as pronounced critics). While the number and content of the compulsory subjects vary across the Commonwealth, there appears to be a common core of five or six of the seven foundations. EU law, inevitably, has less relevance for most and India excludes Equity in an otherwise much more extensive list, while Company and/or Commercial law is included in, for example, Scotland, Canada, Australia and India (see e.g. LETR (2013), para 4.98) but not at the academic stage in England and Wales or Malaysia (see e.g. http://www.malaysianbar.org.my/admission _requirements.html) although Company law (and an element of Succession) are components of the English and Welsh vocational stage for solicitors. It remains to be seen what the SRA decide to do and how collaborative and socially responsible they will be in a diverse rather than unitary legal sector. What seems clear, however, is that the foundation subjects continue to remain central - if potentially somewhat obscured by new additions.

\section{Reference List}

ACLEC. 1996. The Advisory Committee on Legal Education and Conduct - First report on legal education and training.

Bar Standards Board. 2015a. 'Future Bar Training'. Bar Standards Board.

https://www.barstandardsboard.org.uk/media/1650565/future_bar_training_programme_update_february_201 5_pdf_va499362_.pdf.

- - . 2015b. 'Future Bar Training. Professional Statement for Barristers.' Bar Standards Board. https://www.barstandardsboard.org.uk/media/1707496/bsb_professional_statement_2015.pdf. - - - 2016a. 'Future Bar Training Consultation on the Future of Training for the Bar: Academic, Vocational and Professional Stages of Training Summary of responses' (January 2016). Bar Standards Board. 
This is a pre-print of an article that has been accepted for publication in Amicus Curiae (the official journal of the Society for Advanced Legal Studies and the Institute of Advanced Legal Studies (a member institute of the School of Advanced Study, University of London). The definitive version appears in issue 104 and will in time appear at http://ials.sas.ac.uk/digital/sas-open-journals/amicus-curiae/amicus-curiae-2015 and/or http://journals.sas.ac.uk/amicus/issue/archive. This version (C) the authors.

- - - 2016b. 'Future Bar Training. The Professional Statement for Barristers. Consultation on Threshold Standards and Competences.' Bar Standards Board.

https://www.barstandardsboard.org.uk/media/1740972/future_bar_training_threshold_standard_consultation_ document_full_copy_080316.pdf.

Birks, Peter. 1995. 'Compulsory Subjects: Will the Seven Foundations Ever Crumble?' [1995] 1 WebJCLI

General Council of the Bar. 2016. 'Bar Council Response to the Training for Tomorrow: Assessing Competence Consultation Paper'. General Council of the Bar.

http://www.barcouncil.org.uk/media/422472/bar_council_response_to_the_training_for_tomorrow.pdf. Law Society. 2016. 'SRA Training for Tomorrow: Assessing competence: Response of the Law Society of England and Wales'. Law Society of England and Wales.

Law Society, and General Council of the Bar. 1999. 'Joint Statement by the Law Society and the General Council of the Bar on the Academic Stage of Training'. Law Society and General Council of the Bar.

http://www.sra.org.uk/students/academic-stage-joint-statement-bsb-law-society.page.

LETR. 2013. Setting Standards: The Future of Legal Services Education and Training Regulation in England and Wales (The Final Report of the Legal Education and Training Review Independent Research Team).

Smith, C. 2016. 'Profession rounds on SRA over 'super-exam' plan' LSG, 11 March 2016.

Solicitors' Regulation Authority. 2015a. 'Statement of Solicitor Competence'. Solicitors' Regulation Authority. http://www.sra.org.uk/solicitors/competence-statement.page.

- - . 2015b. 'Statement of Legal Knowledge'. Solicitors' Regulation Authority.

http://www.sra.org.uk/knowledge/.

- - 2015c. 'Training for Tomorrow: assessing competence' (7 December 2015). Solicitors' Regulation Authority. http://www.sra.org.uk/documents/SRA/consultations/t4t-sqa-consultation.pdf. 